\title{
BERN RADIOCARBON DATES II
}

\author{
CHR. GFELLER, H. OESCHGER and U. SCHWARZ \\ Physikalisches Institut, Universität Bern
}

This list covers measurements made at the Radiocarbon Dating Laboratory, Physics Department, University of Bern, from spring, 1959, until summer, 1960. We have now two low-level counters working (Houtermans and Oeschger, 1958).

The samples are converted into acetylene. The available amount of most samples was limited, and as peat, gyttja, and especially bone, contain only a few grams of carbon, they are measured routinely at a pressure of $500 \mathrm{~mm}$ $\mathrm{Hg}$.

As hackground samples we use acetylene, produced either from coal or ethylene, derived from crude oil. Recently, we have taken as a modern reference source the activity of NBS-oxalic-acid-standard $x$ 0,950. It agrees, within statistics with our older standards, which were wood formed between A.D. 1850 and 1900. Errors given are the standard deviations derived from the number of counted particles and the statistical errors of hackground and modern standard. Results are calculated with a decay time of $5568 \mathrm{yr}$ for $\mathrm{C}^{14}$; no $\mathrm{C}^{13}$ corrections are made.

Gytta, peat, wood and charcoal samples have been pretreated with hot dilute $\mathrm{HCl}$. For peat samples, in which infiltration of humic acid is to be feared, additional treatment with hot $\mathrm{KOH}$ is applied. Bone samples are charred in a nitrogen atmosphere at $650^{\circ} \mathrm{C}$ and terated with hot dilute $\mathrm{HCl}$ afterwards. Bone and other samples are then converted into acetylene (Suess, 1954), which is stored for (a. one month before measurement. Each sample is then measured in both counters in turn, with an interval of one week to check radon contamination.

About twenty dates of samples from peat borings in the high-alpine region are not reported in this paper, because they are much too young; they have shown activities as much as 20 to $30 \%$ higher than our modern standard. We have excluded the possibility that these samples contain parts of actual living plants. Contamination with $\mathrm{CaC}^{14} \mathrm{O}_{3}$ can also be excluded, because the samples have been treated with hot acid. The source of this contamination is still under study.

Another group of dates left out of this paper is related to dating of the last glacial age. Measured dates lie between 30,000 and 45,000 yr, or are older than $50,000 \mathrm{yr}$. We expect to repeat some of the measurements, with better chemical pretreatment. Moreover, the geologic age of some of these samples is still under discussion.

\section{ACKNOWLEDGMENTS}

This work was made possible by a grant from the "Schweizerischer Nationalfonds". The authors wish to thank Trudi Riesen for the excellent and careful preparation of the samples. Furthermore, they thank Max Welten and H. G. Bandi for their help in selecting and discussing the samples. 


\section{SAMPLE DESCRIPTIONS}

I. QUATERNARY GEOLOGY AND VEGETATIONAL HISTORY

\section{Grindelwald series, Switzerland}

At several places in the village of Grindelwald, (ca. $46^{\circ} 37^{\prime} 30^{\prime \prime} \mathrm{N}$ Lat, $8^{\circ} 2^{\prime} 30^{\prime \prime}$ E Long), alt ca. $1050 \mathrm{~m}$, Bernese Oberland, stems have been excavated during the building of new houses. Some were found in drift of the Obere Grindelwald Glacier; others in prehistoric landslides. Both kinds are of unknown age. Coll. 1958 by Viktor Boss, Grindelwald; subm. by F. G. Houtermans, Univ. of Bern. Comment (by M.W.) : samples not being accurately located, they can be discussed only as a group. The oldest are dated here as of Neolothic age. It is improbable that human influence is responsible for the burial of the three oldest stems. They may therefore be tentatively compared with B-254. (this date list) from Oberaar, by which an advance of the Oberaar Glacier at this time is proved. Younger (19th and 16th century) advances of the Obere Grindelwald Glacier did not quite reach the village, but are known to have alarmed the inhabitants. The younger stems probably were incorporated in landslides of unknown extent during the Bronze and Iron ages. Further investigations will be of more than local interest.

$\begin{array}{lll}\text { B-137. } & \text { Grindelwald, Kirche I } & 2500 \pm 120 \\ \text { B-138. } & \text { Grindelwald, Endweg } & 4700 \pm 160 \\ \text { B-139. } & \text { Grindelwald, Adlerstutz I } & 4400 \pm 120 \\ \text { B-140. } & \text { Grindelwald, Adlerstutz II } & 4400 \pm 120 \\ \text { B-141. } & \text { Grindelwald, Kirche II } & 3400 \pm 120\end{array}$

\section{Khumbu Moraine series, Nepal}

Plant remnants from a well-developed soil profile in alluvial sand and clay, Gorakshep Lake, near Khumbu Glacier, Mount Everest area $\left(27^{\circ} 59^{\prime} \mathrm{N}\right.$ Lat, $86^{\circ} 50^{\prime} 1^{\prime \prime}$ E Long). Coll. 1956 and subm. by Fritz Müller, now at McGill Univ., Montreal, Canada. Comment: Gorakshep Lake lies between two moraines which appeared comparable with the A.D. 1600 and A.D. 1850 moraines in the Alps. The plants must have grown on one or both moraines. Dates prove that both moraines are older than A.D. 1600 (Müller, 1958).

B-174. Khumbu Moraine I, $70 \mathrm{~cm}$ depth

$480 \pm 80$

Plant remnants, several indistinguishable species.

B-173. Khumbu Moraine II, $130 \mathrm{em}$ depth

$1150 \pm 80$

Plant remnants, several indistinguishable species.

\section{Dalpe series, Switzerland}

Peat and gyttja from a bog deposit, Bedrina-Dalpe, near Faido, Canton Ticino $\left(46^{\circ} 29^{\prime} 08^{\prime \prime} \mathrm{N}\right.$ Lat, $8^{\circ} 46^{\prime} 34^{\prime \prime}$ E Long), alt $1235 \mathrm{~m}$. Coll. 1958 by Heinrich Zoller, Univ. of Zürich; subm. by Max Welten, Univ. Bern. Comment: B-179 dates the end of dominant Abies and immigration of Picea abies; B-176 dates immigration of Abie alba $\mathrm{S}$ of the Alps. B-177 dates a deterioration 
of climate in the Preboreal, named "Piottino-Schwankung" by the author. B-178 dates the thermal maximum within the Alleröd S of the Alps (Zoller, 1960).

B-179. Dalpe 1, 107 to $112 \mathrm{~cm}$ depth $5970 \pm 160$ Sedge peat.

B-176. Dalpe 2, 225 to $250 \mathrm{~cm}$ depth $9500 \pm 150$ Sedge peat, with fragments of Abies alba wood.

B-177. Dalpe 3, 295 to $300 \mathrm{~cm}$ depth Peat of Hypnaceae.

B-178. Dalpe 4, 422 to $427 \mathrm{~cm}$ depth Gyttja with clay.

\section{Lago Origlio series, Switzerland}

Gytta from a lake and bog deposit at Lago d'Origlio, $\mathrm{N}$ of Lugano, Canton Ticino ( $46^{\circ} 03^{\prime} 07^{\prime \prime} \mathrm{N}$ Lat, $8^{\circ} 56^{\prime} 55^{\prime \prime}$ E Long), alt $421 \mathrm{~m}$. Coll. September 1958 and 1959 by Heinrich Zoller, Univ. of Zürich; subm. by Max Welten, Univ. of Bern. Comment: B-187 allows the inference that chestnut, Castanes sativa, was brought into this region by man in the Iron (and Roman) ages. B-188 dates first traces of culture of Neolithic man. B-189 dates the initial phase of the Allerød interstadial in low altitudes S of the Alps (H. Zoller, 1960).

B-187. Lago Origlio, 240 to $250 \mathrm{~cm}$ depth

$$
2770 \pm 120
$$

B-188. Lago Origlio, 370 to $380 \mathrm{~cm}$ depth

$4700 \pm 100$

B-189. Lago Origlio, 480 to $490 \mathrm{~cm}$ depth

$$
12,000 \pm 200
$$

B-190. Lago Cadagno, Switzerland

$3250 \pm 100$

Peat mixed with sand from 90 to $102 \mathrm{~cm}$ depth in a bog on the shore of Lago Cadagno, near Lago Ritom, Canton Ticino $\left(46^{\circ} 33^{\prime} 05^{\prime \prime} \mathrm{N}\right.$ Lat, $8^{\circ} 42^{\prime}$ 54" E Long), alt $1925 \mathrm{~m}$. Coll. September 1958 by Heinrich Zoller, Univ. of Zürich; subm. by Max Welten, Univ. of Bern. Comment: the sample dates a phase within the period of Alnus-viridis and Picea (Zoller, 1960).

\section{Fuori Piora series, Switzerland}

Peat from a bog, Cadagno Fuori, near Lago Ritom, Canton Ticino $\left(46^{\circ}\right.$ $33^{\prime}$ N Lat, $8^{\circ} 42^{\prime}$ 14" E Long), alt $1910 \mathrm{~m}$. Coll. 1958 by Heinrich Zoller, Univ. of Zürich; subm. by Max Welten, Univ. of Bern. Comment: B-191 dates the first re-immigration of forest at this alt at the end of Preboreal time (Zoller, 1960).

B-191. Fuori Piora, 50 to $55 \mathrm{~cm}$ depth

$$
\begin{aligned}
& 5100 \pm 100 \\
& 8150 \pm 130
\end{aligned}
$$

B-192. Fuori Piora, 145 to $150 \mathrm{~cm}$ depth

Bitsch-Naters series, Wallis, Switzerland

Gyttja and peat from Bitsch-Naters, Canton Wallis, near Brig $\left(46^{\circ} 20^{\prime}\right.$ 24" N Lat, $7^{\circ}$ 59' 26" E Long), alt 1039 m. Coll. September 1956 by Max 
Welten and Otto Hegg; subm. by Welten, Univ. of Bern. Comment: the filling of this kettle by a thick deposit of pure organic matter after the retreat of the ancient Aletsch Glacier, gives crucially important data on the retreat and on the invasion of vegetation, as well as on later vegetational and climatic changes. Palynological details are unpublished, except for a preliminary note by Welten (1958). Two dates, determined earlier, are to be found in Oeschger, Schwarz and Gfeller (1959), (B-72, $7330 \pm 180 ;$ B-73, $2600 \pm 100)$. The series of 6 dates is fairly consistent internally.
B-197. Bitsch-Naters III, 135 cm depth
$1000 \pm 120$
B-196. Bitsch-Naters III, $234 \mathrm{~cm}$ depth
$1740 \pm 200$
B-195. Bitsch-Naters III, $432 \mathrm{~cm}$ depth
$4170 \pm 120$
B-194. Bitsch-Naters III, 505 cm depth
$5350 \pm 100$

\section{Eggen series, Wallis, Switzerland}

Peat of sedges and Hypnaceae from a bog deposit just behind a lateral moraine of the ancient Aletsch Glacier. The boggy plain behind the moraine is covered by grassland and fields, where rye was cultivated until recently. Locality is $\mathrm{N}$ of Blatten and Brig-Naters, Wallis $\left(46^{\circ} 22^{\prime} 13^{\prime \prime} \mathrm{N}\right.$ Lat, $7^{\circ} 59^{\prime} 22^{\prime \prime}$ E Long), alt $1650 \mathrm{~m}$. Coll. September 1956 by Max Welten and Otto Hegg; subm. by Welten, Univ. of Bern. Comment: material taken from a single boring. The beginning of organic sedimentation after the retreat of Aletsch Glacier was of primary concern. Younger dates will give the chronology of vegetational history, demonstrated by pollen analyses, as yet unpublished. See preliminary note of Welten (1958). The series is fairly self-consistent, though all dates are ca. $1000 \mathrm{yr}$ older than supposed on the basis of the first palynologic researches in 1957.

$\begin{array}{lll}\text { B-201. } & \text { Eggen, } 60 \mathrm{~cm} \text { depth } & 2500 \pm 100 \\ \text { B-200. } & \text { Eggen, } 140 \mathrm{~cm} \text { depth } & 3970 \pm 110 \\ \text { B-198. } & \text { Eggen, } 320 \mathrm{~cm} \text { depth } & 7080 \pm 120\end{array}$

\section{Belalp series, Wallis, Switzerland}

Peat and gyttja from a lake-and-bog deposit above the present forest limit, near the Aletsch Glacier, $\mathrm{N}$ of Brig-Naters, Wallis $\left(46^{\circ} 23^{\prime} 6^{\prime \prime} \mathrm{N}\right.$ Lat, $7^{\circ}$ $59^{\prime} 2^{\prime \prime}$ E Long), alt 2330 m. Coll. September 1959 by Max Welten and Otto Hegg; subm. by Welten, Univ. of Bern. Comment: material taken from a single boring. The beginning of organic sedimentation was to be dated, as well as different stages of the pollen-sequence diagram, as yet unpublished. If the forest ever reached this alt, this event was to be dated, too. A preliminary note was published by Welten (1958).
B-205. Belalp, $62.5 \mathrm{~cm}$ depth
$1920 \pm 90$
B-203. Belalp, $122.5 \mathrm{~cm}$ depth
$5820 \pm 120$
B-202. Belalp, $147.5 \mathrm{~cm}$ depth
$6130 \pm 110$ 
B-254. Oberaar-Grimsel Resevoir, Switzerland

$4600 \pm 80$

Trunks of fir (Pinus cembra), excavated during construction of resevoir of Oberaar (46 $32^{\prime} 46^{\prime \prime} \mathrm{N}$ Lat, $8^{\circ} 15^{\prime} 55^{\prime \prime}$ E Long), alt $2240 \mathrm{~m} \mathrm{~W}$ of Grimsel Pass, Bernese Oberland. The wood, so well preserved that it was used as fuel, came from an end moraine of the Oberaar Glacier, now drowned by the resevoir; it was supposed to record one of the last advances of the glacier, in A.D. 1860 or 1808, or perhaps about A.D. 1600 . Coll. 1952 by different persons, reported by Hugo Maler, Bern; subm. by Max Welten, Univ. of Bern. Comment: the result is surprising and of great interest in history of glaciation and of former treelines. Details of this and other local glacial advances and retreats are still not clear. B-138, B-139, and B-140 (this date list) give evidence of advance of the Oberer Grindelwald Glacier at about the same time.

\section{Grächen series, Wallis, Switzerland}

Sedge and moss peat from a boring in a small lake behind a lateral moraine of the ancient glacier of Nikolai valley, a little above the village of Grächen $\left(46^{\circ} 11^{\prime} 48^{\prime \prime} \mathrm{N}\right.$ Lat, $7^{\circ} 50^{\prime} 43^{\prime \prime} \mathrm{E}$ Long), alt $1720 \mathrm{~m}$. near Visp and Stalden, Wallis. Coll. and subm. July 1951 by Max Welten, Univ. of Bern. Comment: Grächen being the driest locality in Switzerland, it is of special interest to investigate its vegetational history by means of palynology and $\mathrm{C}^{14}$ dating. A preliminary note was published by Welten (1958). The series is consistent with the exception of B-262, which is incomprehensible and will be repeated. The pollen profile shows unusually strong fluctuations of the larch curve, of which at least the older ones are considered to reflect climatic changes.

\section{B-261. Grächen, $238 \mathrm{~cm}$ depth \\ B-260. Grächen, $408 \mathrm{~cm}$ depth \\ B-259. Grächen, $536 \mathrm{~cm}$ depth \\ B-258. Grächen, $630 \mathrm{~cm}$ depth \\ B-262. Grächen, $709 \mathrm{~cm}$ depth}

B-283. La Trelasse, Switzerland, $510 \mathrm{~cm}$ depth

Peat in a well-developed sphagnum bog at ( $46^{\circ} 26^{\prime} 51^{\prime \prime} \mathrm{N}$ Lat, $6^{\circ} 5^{\prime} 43^{\prime \prime}$ E Long), W part of Jura mountains, alt $1242 \mathrm{~m}$. Sample was taken to complete a series taken in October 1956, two dates of which have been published (B-87 and B-88, Bern I). Coll. July 1959 by Samuel Wegmüller; subm. by Max Welten, Univ. of Bern. Comment: sample dates end of the phase of hazel and the beginning of Quercetum mixtum.

\section{B-284. Lac de L'Abbaye, France, $403.3 \mathrm{~cm}$ depth $9050 \pm 120$}

Gyttja, mixed with clay and chalk, from a boring in Lac de L'Abbaye, near St. Laurent $\left(46^{\circ} 31^{\prime} 36^{\prime \prime} \mathrm{N}\right.$ Lat, $5^{\circ} 54^{\prime} 13^{\prime \prime} \mathrm{E}$ Long), alt $871 \mathrm{~m}$, in the French Jura. Coll. 1957 by Samuel Wegmüller; subm. by Max Welten, Univ. of Bern. Comment: B-284 may date the invasion of hazel in the western Jura, if no redeposited carbonate contributed to the sample. 


\section{Lac de Narlay series, France}

Gyttja mixed with chalk (B-285) and peat (B-286) from Lac de Narlay, near Le Frasnois, French Jura $\left(46^{\circ} 38^{\prime} \mathrm{N}\right.$ Lat, $5^{\circ} 54^{\prime} \mathrm{E}$ Long $)$, alt $748 \mathrm{~m}$. Coll. July 1957 by Samuel Wegmüller; subm. by Max Welten, Univ. of Bern. Comment: B-285 dates a time shortly after the beginning of invasion of Abies and Fagus. It is a very long phase. This dating does not contradict B-88 ( $5340 \pm 100$, La Trelasse $340 \mathrm{~cm}$, Bern I), because the 1957 studies refer to a different section. B-286 dates a later rise of Abies pollen after the long period of dominance.

$$
\begin{array}{ccc}
\text { B-285. Lac de Narlay, } 673.3 \mathrm{~cm} \text { depth } & 4720 \pm 100 \\
\text { B-286. } \quad \text { Lac de Narlay, } 95.2 \mathrm{~cm} \text { depth } & 1050 \pm 80 \\
\text { B-287. Lac de Chalain, France, } 75.5 \mathrm{~cm} \text { depth } & 2700 \pm 100
\end{array}
$$

Dry peat from the shore of Lac de Chalain, near Champagnole, French Jura (46 40 $\mathrm{N}$ Lat, $5^{\circ} 47^{\prime} \mathrm{E}$ Long), alt $488.4 \mathrm{~m}$. Coll. August 1957 by $\mathrm{H}$. Balmer and Samuel Wegmüller; subm. by Max Welten, Univ. of Bern. Comment: sample supposedly dates the end of the period of Quercetum mixtum, but seems to be too young. The reason for this is not known.

\section{Les Cruilles series, Switzerland}

Peat in a well-developed sphagnum bog at Les Cruilles, near Le Pont, Vallee de Joux (46 $39^{\prime} 49^{\prime \prime}$ N Lat, $6^{\circ} 18^{\prime} 36^{\prime \prime}$ E Long), alt 1040 m, western Jura. Coll. 1958 by Samuel Wegmüller; subm. by Max Welten, Univ. of Bern. Comment: all dates are from a single peat profile and form a consistent and reasonable series from the beginning of the Quercetum mixtum phase in western Jura.

B-288. Les Cruilles, $324 \mathrm{~cm}$ depth

$7060 \pm 100$

The beginning of Quercetum mixtum phase.

B-289. Les Cruilles, $199.8 \mathrm{~cm}$ depth

$\mathbf{5 5 7 0} \pm 120$

The end of the Quercetum mixtum phase.

B-290. Les Cruilles, $98.8 \mathrm{~cm}$ depth

$4170 \pm 140$

The first dominance of Picea.

B-292. Seche de Gimel, Switzerland, $380.3 \mathrm{~cm}$ depth $6360 \pm 120$

Peat in a sphagnum bog (Sèche de Gimel), near Col de Marchairuz $\left(46^{\circ}\right.$ $33^{\prime} 05^{\prime \prime} \mathrm{N}$ Lat, $6^{\circ} 14^{\prime} 00^{\prime \prime}$ E Long), alt $1300 \mathrm{~m}$, in western Jura. Coll. 1958 by A. Wasserfallen and Samuel Wegmüller; subm. by Max Welten, Univ. of Bern. Comment: sample dates the culmination of the Quercetum-mixtum phase in the western Jura and agrees very well with results of the series from Les Cruilles (B-288, B-289, this date list).

\section{Fagne Wallonne series, Belgium}

Fragments of wood found in a layer of peat, Fagne Wallonne, near Liège ( $50^{\circ} 30^{\prime} 56^{\prime \prime}$ N Lat, $6^{\circ} 06^{\prime} 38^{\prime \prime}$ E Long). Coll. March 1960 by R. Schumacker; subm. by Prof. Duchesne, Liège University. Comment: samples were taken in 
a peat pit. For palynology, see Florschutz and van Oye (1946), and Persch (1950).

B-297. Fagne Wallonne 1, $220 \mathrm{~cm}$ depth $\quad 6720 \pm 120$

Fragments of trunks (Betula pubescens). Pollen zone: Atlantic.

B-298. Fagne Wallonne 2, $110 \mathrm{~cm}$ depth $\quad 4690 \pm 100$

Fragments of branches (Betula pubescens, Vaccinium uliginosum). Pollen zone: Subboreal.

$$
\text { II. ARCHAEOLOGIC SAMPLES }
$$

\section{Mottata series, Ramosch, Switzerland}

Charcoal from Mottata, a cave inhabited from middle Bronze Age until late Iron Age, near Ramosch, Unter-Engadin, Canton Graubünden ( $46^{\circ} 50^{\prime}$ $15^{\prime \prime} \mathrm{N}$ Lat, $8^{\circ} 23^{\prime} 20^{\prime \prime} \mathrm{E}$ Long), alt $1524 \mathrm{~m}$. Coll. July and August 1956 by Benedikt Frei; subm. by H. G. Bandi, Historisches Museum, Bern. Comment: the ages seem to be a little too high, but archaeologic knowledge about these culture layers is poor (Frei, 1959).

\section{B-145. Mottata 2}

$3060 \pm 100$

Charcoal from upper "Melaunerhorizont" (Ceramic type Hallstatt C).

\section{B-146. Mottata 5}

$2850 \pm 130$

Charcoal from a rafter of a late-Iron-Age house (probably early phase of "Fritzens-Sanzenhorizont").

\section{B-147. Mottata 9}

$3320 \pm 100$

Charcoal from deeper layer of lower "Melaunerhorizont" (Urnenfelder. zeit, probably Hallstatt A).

\section{B-148. Mottata 13}

Charcoal from older "Melaunerhorizont" (Urnenfelderzeit).

B-149. Mottata 14

$\mathbf{3 5 5 0} \pm \mathbf{1 0 0}$

Charcoal from middle Bronze Age.

\section{B-163. Homberg-Kuettigen, Switzerland} (47. $25^{\prime} 17^{\prime \prime} \mathrm{N}$. Lüthi, Aarau. Comment: the result shows that the piece of wood comes from a fireplace of men who cleared this region, and does not originate from a prehistoric settlement.

\section{Schiers series, Switzerland}

Wood and charcoal samples from an early-medieval burial place near Schiers, Canton Graubünden (46 $56^{\circ} 3^{\prime \prime} \mathrm{N}$ Lat, $7^{\circ} 21^{\prime} 15^{\prime \prime}$ E Long). Coll. 1956 by Hans Erb; subm. by H. G. Bandi, Historisches Museum, Bern. Comment: the ages of the three samples are in agreement with archaeologic chronology.

B-165. Schiers II

Charcoal from level of skeleton, tomb II, in scree.

$$
1680 \pm 100
$$


B-166. Schiers III

$1430 \pm 80$

Charcoal from fireplace ahove skeleton (above B-165), tomb II.

B-168. Schiers V

$1640 \pm 100$

Wood from level of skeleton, tomb III, in scree.

\section{Ranggiloch-Boltigen series, Switzerland}

Bones from two hear-bone layers and three pieces of wood stuck perpendicularly in these layers, in shelter-cave at Ranggiloch, near Boltigen. Bernese Oberland ( $46^{\circ} 38^{\prime} 20^{\prime \prime} \mathrm{N}$ Lat. $7^{\circ} 20^{\prime} 27^{\prime \prime}$ E Long), alt $1845 \mathrm{~m}$. Coll. 1933 and 1946 by David and Albert Andrist and Walter Flükiger; subm. by H. G. Bandi, Historisches Museum, Bern. Comment: both layers are more or less disturbed and mixed. The upper layer contains material washed up from the deeper layer (Schmid, 1958). The wood samples (B-154, B-206, B-207) are younger than the bones. and therefore are supposed to have fallen from overhanging rocks, late in postglacial time, as is also implied by the ecology of the trees.

B-152. Ranggiloch

$10,150 \pm 200$

Bones from upper hear-bone layer (Lrsus arctos spelaeus).

B-153. Ranggiloch

$9500 \pm 150$

Bones from lower bear-hone layer.

B-154. Ranggiloch

$4800 \pm 90$

Picea abies wood.

B-206. Ranggiloch

$4920 \pm 130$

Pinus cembra wood.

B-207. Ranggiloch

$4700 \pm 80$

Picea abies wood.

\section{Podstrana series, Jugoslavia}

Bones of man from old-Croatian grave-mounds, excavated at PodstranaOmiš, near Split, province Hrvatska (4:3 $29^{\prime} 20^{\prime \prime}$ N Lat, $16^{\circ} 35^{\prime} 5^{\prime \prime}$ E Long). Coll. August 1958 and subm. by Father Ante Skobalj of Krilo-Jesenice. Comment: B-216 and B-218 were very small samples, and could only be measured at half the normal pressure. Both dates seem to be too young, because the bones came from a pre-Christian, old-Croatian type of grave. B-217, originating from a medieval (Christian) old-Croatian grave, gives the expected age.

B-216. Podstrana 1

B-217. Podstrana 2

B-218. Podstrana 3

B-233. Umtali, Southern Rhodesia

Charcoal found in a niche below an iron-furnace in a kraal (walled village) of Ingyanga culture, near the Zewa farm, Umtali, Southern Rhodesia (18 $55^{\prime} \mathrm{S}$ Lat, $32^{\circ} 33^{\prime} \mathrm{E}$ Long). Coll. 1958 by F. O. Bernhard, Umtali; 
subnı. by H. G. Bandi, Historisches Museum, Bern. Comment: the sample was taken in the deepest culture layer found, accompanied by pottery of a preIngyanga culture.

\section{Birsmatten-Basishöhle series, Switzerland}

Bone from Birsmatten-Basishöhle cave-dwelling, with five Mesolithic culture layers, at Nenzlingen, near Laufen, Canton Bern $\left(47^{\circ} 25^{\prime} 43^{\prime \prime} \mathrm{N}\right.$ Lat, $70^{\circ} 33^{\prime} 3^{\prime \prime}$ E Long). Coll. 1955 and 1956 and subm. by H. G. Bandi, Historisches Museum, Bern. Comment: errors given are relatively high, because samples were half the normal size.

B-234. Birsmatten-Basishöhle 1 b

Bones from layer 1 (Tardenoisian?).

B-235. Birsmatten-Basishöhle 2 b

Bones from layer 2 (Tardenoisian?).

B-236. Birsmatten-Basishöhle 3 b Bones from layer 3 (Sauveterrian?).

B-238. Birsmatten-Basishöhle 5 b Bones from layer 5 (Sauveterrian?).

B-232. St. Léonard, Switzerland

Soil formed by decomposition of wood from a Neolithic culture layer, in habited during the Cortaillod-Chassey-Lagozza-period, at St. Léonard, near Sierre, Wallis ( $46^{\circ} 15^{\prime} 28^{\prime \prime} \mathrm{N}$ Lat, $7^{\circ} 25^{\prime} 36^{\prime \prime} \mathrm{E}$ Long), alt $592 \mathrm{~m}$. Coll. by M. R. Sauter, Univ. of Geneva; subm. by Max Welten, Bern. Comment: it is the first age determination of this kind in Canton Wallis (Sauter, 1959 and 1960), and no definite conclusion can be drawn out.

\section{B-246. Alt-Landenberg, Switzerland}

$500 \pm 100$

Fragments of shingle-wood, discovered by excavating bottom of moat at ruin of Alt-Landenberg castle, near Bauma, Canton Zurich $\left(47^{\circ} 22^{\prime} 28^{\prime \prime} \mathrm{N}\right.$ Lat, $8^{\circ} 52^{\prime} 10^{\prime \prime}$ E Long). Coll. 1958 by P. Ziegler; subm. by H. G. Bandi, Historisches Museum, Bern. Comment: result shows that the moat, now filled, must have been open until about A.D. 1500.

\section{B-247. Tierberghoehle, Switzerland}

$\mathbf{2 1 4 0} \pm \mathbf{8 0}$

Charcoal from uppermost of three layers containing hearths, in the Tierberghohle, a high-alpine cave near Lenk, Bernese Oberland $\left(40^{\circ} 23^{\prime} 25^{\prime \prime} \mathrm{N}\right.$ Lat, $5^{\circ} 28^{\prime} 18^{\prime \prime}$ E Long), alt 2600 m. Coll. 1937 by David and Albert Andrist and Walter Flükiger; subm. by H. G. Bandi, Historisches Museum, Bern. Comment: the cave was used as shelter until the Iron Age. For excavation data see Andrist and Flükiger (1937).

\section{B-244. Seeberg Burgaeschisee-Siid 1 (B-114 bis) $4790 \pm 120$}

Charcoal from a settlement of Younger Cortaillod culture, inhabited near the end of the "Vollneolithikum" of Switzerland, at Burgaeschisee, near Seeberg, Canton Bern ( $47^{\circ} 11^{\prime} \mathrm{N}$ Lat, $7^{\circ} 40^{\prime} \mathrm{E}$ Long). Coll. October 1957 from charcoal layer below a thin zone of loam, overlying a sequence of loam and 
charcoal layers, by Hansjürgen Müller-Beck; subm. by H. G. Bandi, Historisches Museum, Bern. Comment: the result fits somewhat better with the archaeologic explanation (H. Müller-Beck, Oeschger and Schwarz, 1958) than did the original figure, $4390 \pm 80$ (Bern I). The reason for the discrepancy is not known.

B-245. Seeberg Burgaeschisee-Süd 5B (B-118B bis) $4630 \pm 120$

Bone fragments from a settlement of Younger Cortaillod culture, inhabited near end of "Vollneolithikum" of Switzerland, at Burgaeschisee, near Seeberg, Canton Bern ( $47^{\circ} 11^{\prime} \mathrm{N}$ Lat, $7^{\circ} 40^{\prime} \mathrm{E}$ Long). Coll. November 1958 from the upper third of the culture layer, by H. Müller-Beck; subm. by H. G. Bandi, Historisches Museum, Bern. Comment: the result fits well with the first determination; see B-118B, $4630 \pm 180$ (Bern I), and Müller-Beck, Oeschger and Schwarz (1958). (Seeberg-Burgaeschisee-Sud 1 (B-114) and SeebergBurgaeschisee-Sud 5B (B-118B) have been re-run with better chemical pretreatment in our laboratory as samples B-244 and B-245, because both samples gave extreme ages of the first series).

B-271. Prins-Bois, Switzerland

$1640 \pm 100$

Charcoal found with fragments of Roman bricks during excavation of primitive iron-working site, at Prins-Bois forest, near Orbe, Canton Waadt ( $46^{\circ} 39^{\prime} 55^{\prime \prime} \mathrm{N}$ Lat, 6 $6^{\circ} 6^{\prime} 46^{\prime \prime} \mathrm{E}$ Long), alt $725 \mathrm{~m}$. Coll. 1959 by P. L. Pelet, Univ. of Lausanne; subm. by H. G. Bandi Historisches Museum, Bern. Comment: the date confirms the age inferred from archaeologic considerations (Pelet, 1960).

$\begin{array}{ll}\text { B-274. Arbon, Switzerland } & 1030 \pm 120\end{array}$

Post wood from old harbor construction in Bodensee, near Arbon, Canton Thurgau ( $47^{\circ} 30^{\prime} 45^{\prime \prime} \mathrm{N}$ Lat, $9^{\circ} 26^{\prime} 30^{\prime \prime} \mathrm{E}$ Long), taken at low-water level. Coll. 1959 and subm. by Willy Schädler, Arbon. Comment: the remains of this construction are described as Roman on old maps. The result shows that it is medieval.

\section{Cape Krusenstern series, NW Alaska, U. S.}

Wood and charcoal samples from archaeologic sites, and peat in a similar situation, on old beach ridges at Cape Krusenstern, NW Alaska, U. S. $\left(67^{\circ} 7^{\prime}\right.$ $\mathrm{N}$ Lat, $163^{\circ} 40^{\prime} \mathrm{W}$ Long). Archaeologic samples coll. July 1959 under direction of J. L. Giddings, Brown University, Providence, Rhode Island, U. S. A.; subm. by H. G. Bandi, Historiches Museum, Bern; peat (B-265) coll. by G. W. Moore, U. S. Geol. Survey. Comment: the different places of archaeologic excavation were expected to give different ages, corresponding to their distance from the modern seashore; house 25, medieval; houses 17 and 18, Ipiutak period; house 21, older than Ipiutak. The dates agree with expectation, and with other dates for these Eskimo cultures. However, the gravel underlying the peat collected by Moore is also beach ridge, deposited when sealevel stood ca. 3 to $4 \mathrm{~m}$ above its present level, and appears to be much older than the ridgesites excavated by Giddings. At least the date of B-265 rules out the possibility that the 3 to $4 \mathrm{~m}$ high stand was occupied in Hypsithermal time. 
B-281. Cape Krusenstern, house 25

Remains of food from bowls.

B-266. Cape Krusenstern, house 17

$1450 \pm 80$

Charcoal.

B-280. Cape Krusenstern, house 18

$1250 \pm 100$

Charcoal.

B-267A. Cape Krusenstern, house 21

$2470 \pm 150$

Charcoal.

B-267B. Cape Krusenstern, house 21

$2530 \pm 150$

Fragments of wood.

B-265. Cape Krusenstern, house 59

$26,100 \pm 400$

Peat-like material overlying a former beach ridge (Ame/Tikizat-1-3).

\section{REFERENCES}

Andrist, David and Albert, and Flükiger, Walter, 1937, Die Tierberghöhle; eine hochalpine neolithische Station: Bern Hist. Mus. Jahrb., v. 14.

Bern I.: see Oeschger, Schwarz, and Gfeller, 1959.

Florschütz, F. F., and van Oye, E. L., 1946, Recherches palynologique dans la region des Hautes Fagnes belges: Biologisch. Jahrb. Dodonaea, dertiende jaargang.

Frei, Benedikt, 1959, Die Ausgrabungen auf der Mottata bei Ramosch im Unterengadin 1956-1958: Jahrb. der Schweiz. Gesell. für Urgeschiehte 4F, 1958/59, pages unknown.

Houtermans, F. G., and Oeschger, Hans, 1958, Proportionalzählrohr zur Messung schwacher Aktivatäten weicher $\beta$-Strahlung: Helvetica Phys. Acta, v. 31, p. 117-126.

Müller, Fritz, 1958, Eight months of glacier and soil research in the Everest region: The Mountain World, 1958-59, Swiss Found. for Alpine Research, p. 191-208.

Müller-Beck, Hansjurgen, Oeschger, Hans, and Schwarz, Ulrich, 1958, Zur Altersbestimmung der Station Seeberg/Burgäschisee-Süd: Bern Hist. Mus. Jahrb., v. 38, p. 272 281 .

Oeschger, Hans, Schwarz, Ulrich, and Gfeller, Christian, 1959, Bern radiocarbon dates I: Am. Jour. Sci. Radioc. Supp., v. 1, p. 133-143.

Pelet, P. L., 1960, Une industrie de fer primitive au pied du Jura Vaudois; la ferrière de Prins-Bois et ses voisins: Vaudoise Hist. Rev., June 1960, p. 49-110.

Persch, F., 1950, Zur postglazialen Wald-und-Moosentwicklung im Hohen Venn: Dechiniana, v. 104, p. 81-93.

Sauter, M. R., 1959, Prehistoire du Valais, des origines aux temps merovingiens: Vallesia, Sion, v. 15 , p. $264-270$.

1960, Le Neolithique de St. Léonard, Valais: Ur-Schweiz-La Suisse primitive,

Schmid, Elisabeth, 1958, Höhlenforschung und Sedimentanalyse. Ein Beitrag zur Datierung des alpinen Paläolithikums: Schriften des Inst. für Ur-und Frühgeschichte der Schweiz, no. 13, Basel 1958, pages unknown. v. 24 , no. 2 , p. $27-32$.

Suess, H. E., 1954, Natural radiocarbon measurements by acetylene counting: Science, v. 120 , p. $5-7$.

Welten, Max, 1958, Die spätglaziale und postglaziale Vegetations-Entwicklung der BernerAlpen und Voralpen und des Walliser Haupttales: Geobot. Inst. Rübel, Zürich, Veröffentl., no. 34 , p. $150-158$.

Zoller, Henrich, 1960, Pollenanalytische Untersuchungen zur Vegetationsgeschichte der insubrischen Schweiz: Denkschr. Schweiz. Naturf. Gesell., v. 83, no. 2, p. 45-152. 